\title{
GUILLAUME DE MACHAUT: NOTATION AND THE COMPOSITIONAL PROCESS
}

\author{
Marie Louise GöLLNER
}

\begin{abstract}
In recent scholarship it has been increasingly emphasized that Machaut, particularly in his later secular chansons, developed a new ideal of vertical sound, namely one which rested on a three- rather than a two-voice basis. The present article links this innovation to the composer's layered concept of notation and to the linear individuality of each of the three voices as evidenced by his use of repeated rhythmic motifs in the ballades of the late narrative poem, Le voir dit.
\end{abstract}

\section{Resumen}

En recientes estudios se ha enfatizado cada vez más que Machaut, particularmente en sus últimas chansons profanas, desarrolló un nuevo ideal de verticalidad musical, basado concretamente en tres, en lugar de dos voces. El presente artículo relaciona esta innovación con el concepto de notación estratificada del compositor y con la individualidad lineal de cada una de las tres voces, como se pone de manifiesto por su uso de motivos rítmicos repetidos en las baladas del poema narrativo tardío, Le voir dit.

Within the rapidly changing notational practices of the late 13th and 14th centuries the secular works, i.e. the chansons, of Machaut form a kind of oasis. Although complicated in many ways, their notation does represent a logical approach to the challenges of dealing with a multilevel system, which now includes duple as well as triple values. Machaut has used this system to develop a highly flexible rhythm for his chansons, which differs on the one hand from the rigid patterns of contemporary isorhythmic motets - including his own - and on the other from the extravagently complicated syncopations of later 14th-century chansons.

It has perhaps not been emphasized enough that Machaut's main interest in the rhythm of these works concerns the many-faceted possibilities of subdividing the breve and that, similar to the works of the early Italian Trecento, that entity tends to remain intact within a given work, i.e. it can serve as the basis for the modern measure. This fact can be easily overlooked, since unfortunately neither of the editions of his works makes any real effort to reflect the original notation of the chansons. ${ }^{1}$ We will return to this point a little later.

1. Fr. Ludwig, ed., Guillaume de Machaut. Musikalische Werke, Vol. I: Balladen, Rondeaux und Virelais, Leipzig 1926; L. Schrade, ed., The Works of Guillaume de Machaut, Second Part (Polyphonic Music of the Fourteenth Century, Vol. III), Monaco 1971. Our examples are taken from the earlier edition, mainly because of its more compact format.

Anuario Musical, 56 (2001) 
Machaut's rhythmic patterns, however, are entirely different from those of his Italian contemporaries, best represented by the middle generation of mainly Florentine composers, ${ }^{2}$ who in the upper voices of their madrigals exploited the rapid-fire patter of minims within both duple and triple divisions:

\section{Example 1}
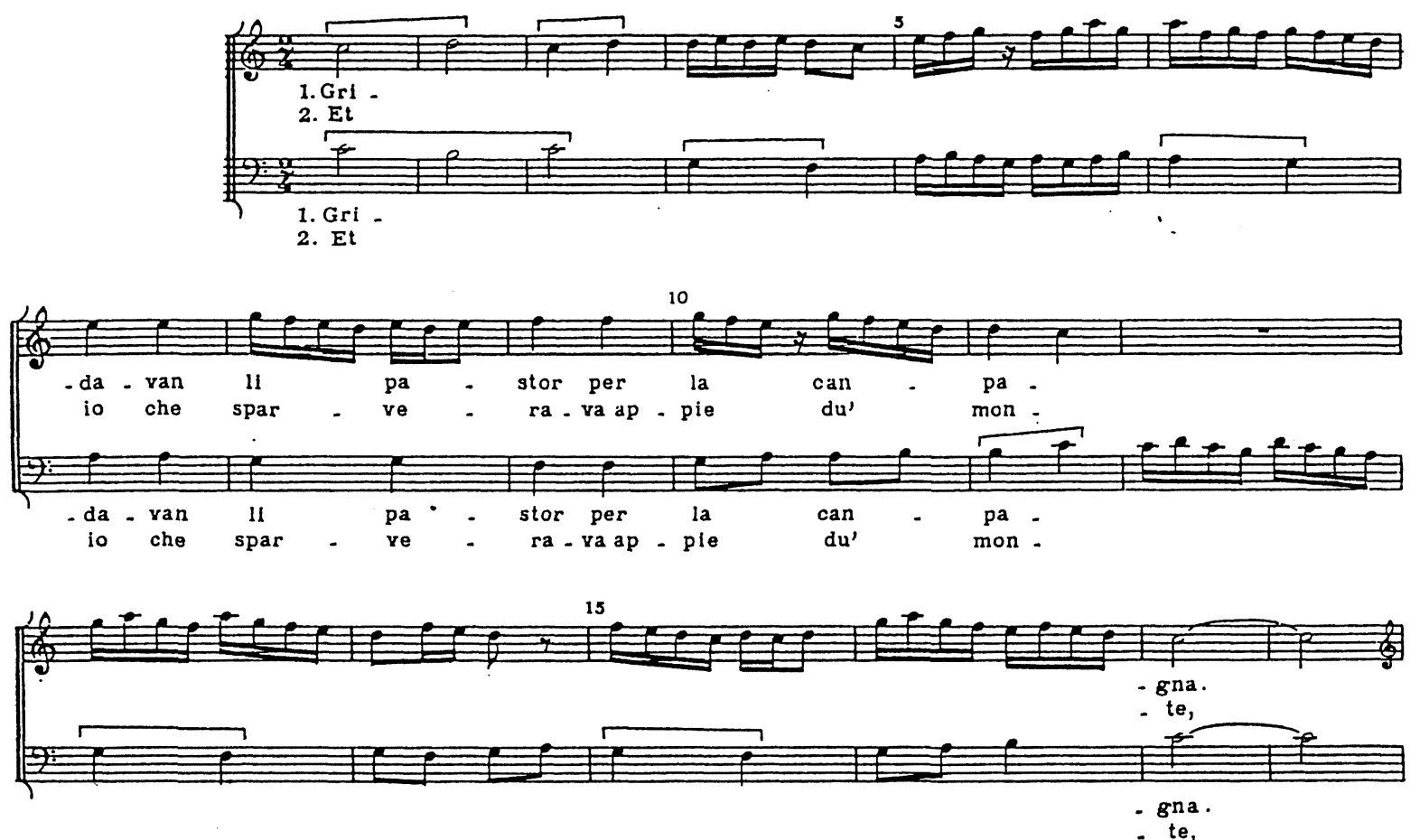

Vincenzo da Rimini: Gridavan li pastor

These small values were, moreover, independent of the text declamation, which followed the more or less regular semibreves of the lower voice. As a result there was for the listener often no clear differentiation between duple and triple subdivision of the breve - minims and even semiminims dominated both - and in fact some works could be notated in any one of several mensurations.

Machaut took an entirely different approach to rhythm, both in the form of recurring motifs and in the declamation of the text. In the former he developed distinctive patterns which,

2. E.g. Gherardello, Lorenzo Masini, Donato da Firenze and Vincenzo da Rimini, all of whom composed in the period ca. 1350-75, during roughly the same years, that is, as Machaut. Their secular works are edited by W. Thomas Marrocco as Vol. VII of Polyphonic Music of the Fourteenth Century, Monaco 1971. Example 1, Gridavan li pastor by Vincenzo da Rimini, is found there on p.7f. 
as has long been noted, ${ }^{3}$ were melodic as well as rhythmic, and declamation of the text became, in contrast to the regular syllabic progression of the Italians, highly varied. Whereas throughout the Trecento, the integrity of the poetic line was strictly retained as the determining factor for the musical phrase as reflected in the cadences, ${ }^{4}$ Machaut was free to divide it into shorter phrases. And he realized this in ways which went far beyond the natural subdivision of the decasyllabic line into four plus six. These smaller units could then be contrasted with each other in slower or more rapid declamation of the syllables, and they formed a kind of counter-balance or counterstructure to the poetic line itself: ${ }^{5}$

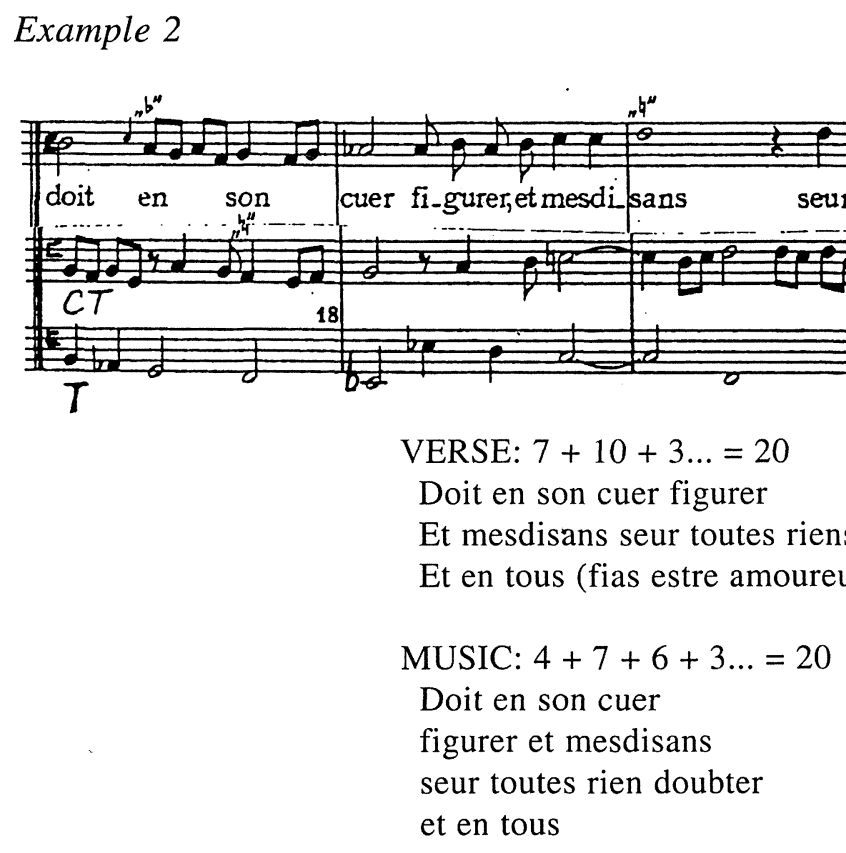

From B25, Honte paour

Both structures, that is, the poetic and the musical, could exist simultaneously and complement rather than duplicate each other. ${ }^{6}$ pp.40-58.

3. See, for example, G. Reaney, "The Ballades, Rondeaux and Virelais of Guillaume de Machaut," Acta 27 (1955),

4. See M.L. Martinez, Musik des frühen Trecento (Münchner Veröffentlichungen zur Musikgeschichte, Vol. 9), Tutzing 1963, pp.16ff.

5. See M.L. Göllner, "Musical and Poetic Structure in the Refrain Forms of Machaut," in Liedstudien. Wolfgang Osthoff zum 60. Geburtstag, ed. M. Just and R. Wiesend, Tutzing 1989, pp.61-76.

6 . The poems themselves reflect a similar construction, consisting of co-existing layers of meaning of an often subtle and complicated nature. This applies even to the long narrative poems, as described by various modern literary scholars. See, for example, the shifting function of the "persona" or "poetic I" from narrator to poet to participant, as described by Kevin Brownlee in his Poetic Identity in Guillaume de Machaut, Madison, WI 1984; or Jacqueline Cerquiglini, "Un Engin si soutil": Guillaume de Machaut et l'écriture au XIVe siècle, Geneva-Paris 1985. 
And this possibility is, I feel, directly related to the given concept of layered values within the notational system, which allows different subdivisions to co-exist. For Machaut's rhythmic formulae consciously exploit and differentiate the possibilities inherent in the triple or the duple subdivision of values. With very few exceptions these formulae are defined, as noted above, at the level of the breve and semibreve, i.e. tempus and prolation. Modus, except for a few early, generally two-voice works (e.g. B6, Doulx amis) tends to be disregarded as a real value in these secular works and can thus change in the course of a piece, a practice which becomes increasingly evident in the later works. ${ }^{7}$

In the present paper I want to concentrate on Machaut's innovations in compositional practice by linking these rhythmic units to new aspects of vertical sound in a group of his late chansons, namely those included in Le voir dit. This long poetic work, dedicated to the (fictitious?) lady of his heart, can be dated around $1363 .{ }^{8}$ It includes, besides the narrative poem, both an exchange of letters between the two participants, in prose, and, according to the custom of the time, various lyric insertions. Daniel Leech-Wilkinson, in his investigation of the work, ${ }^{9}$ has pointed to various similarities among the few of its lyric poems which Machaut actually set to music. (Only the late manuscript E, Paris, BN f.fr. 9221, includes the music within the literary work).

Specifically, he groups together four of the late ballades (Nos. 32, 33 34, 36) and the Rondeau No.17, which contains an anagram of the name, Peronne, all probably composed, like the poem itself, in 1362-63. With the exception of the dual-texted Ballade 34 (Quant Theseus/Ne quier veoir), which has two superius voices, ${ }^{10}$ all are written for three parts: texted superius plus tenor and contratenor. Although Mr. Leech-Wilkinson and I arrived -in the same year, 1993at completely different explanations for the German connections of "ung res d'alemaigne" for Ballade 33 (Nes qu'on porroit), ${ }^{11}$ I can underscore for the most part his conclusions regarding the composition of this late group of works. In my opinion, however, one important aspect needs further investigation. With this in mind, I should like to look more closely at two of his observations:

7. For an earlier example, in which the changes are clearly visible in the editions, see Ballade No. 10, Ne penses pas, particularly the second main section, mm. 46 to the end (Ludwig, p.9; Schrade, p.81). A facsimile of the piece can be found in W. Apel, The Notation of Polyphonic Music 900-1600, Cambridge, Mass. 1953, p.353 (Facs. 68).

8. The question of authenticity of this "True Account" of the love affair between the aging poet and a young girl has caused considerable discussion among literary scholars. Can it be considered autobiographical and, if so, can Toute-Belle, as she is called in the poem, or Peronne, as revealed in an anagram, be identified, or is this simply a literary construct? For a summary of the various suggestions see William Calin, A Poet at the Fountain. Essays on the Narrative Verse of Guillaume de Machaut, Lexington, KY 1974, pp.168ff. Kevin Brownlee, after examining the different possibilities, finally dismisses the question as unproductive (Poetic Identity 1984, p.239, fn. 25).

9. D. Leech-Wilkinson, "Le Voir Dit and La Messe de Nostre Dame: Aspects of Genre and Style in the Late Works of Guillaume de Machaut," Plainsong and Medieval Music 2 (1993), pp.43-73. See also his recent edition, Le Livre dou Voir Dit (The Book of the True Poem), with English translation by R. Barton Palmer, 1998.

10. For an analysis of this ballade see H. Kühn, Die Harmonik der Ars nova, Munich 1973, pp.159-63, and D. Leech-Wilkinson, Op.cit. 1993, pp.57ff.

11. D. Leech-Wilkinson, Op.cit. 1993, pp.50ff; M.L. Göllner, "Un res d'alemaigne," in Festschrift für Horst Leuchtmann zum 65. Geburtstag, Tutzing 1993, pp.147-60. In the new edition (see fn. 9) Palmer translates the phrase simply as "in the German style" (p.125). 
1) Several of the ballades share melodic and rhythmic motifs.

2) Since tenor and contratenor alternate in presenting the lowest notes, the pieces must have been conceived as 3 -voice from the beginning.

Let us begin with the second point, since the question of three-part writing has been given rather massive scholarly treatment. The history of conflicting views on this process, as found in both German and English literature, has recently been summarized in detail by Kevin Moll. ${ }^{12}$ Very briefly, the views advanced since the 1950 s by Ernst Apfel and even earlier by the Munich school have been largely accepted, namely that three-voice writing in the 14th century rests solidly on a two-voice contrapuntal basis. For the chansons this unit is provided by superius and tenor, to which a third part, or contratenor, is then added. ${ }^{13}$ This third part fills out the sonorities but, as we all too easily forget, it also serves as a rhythmic counterpoint, often of a lively nature, to the more staid progression of the tenor. Many of Machaut's chansons reflect this procedure:

\section{Example 3}

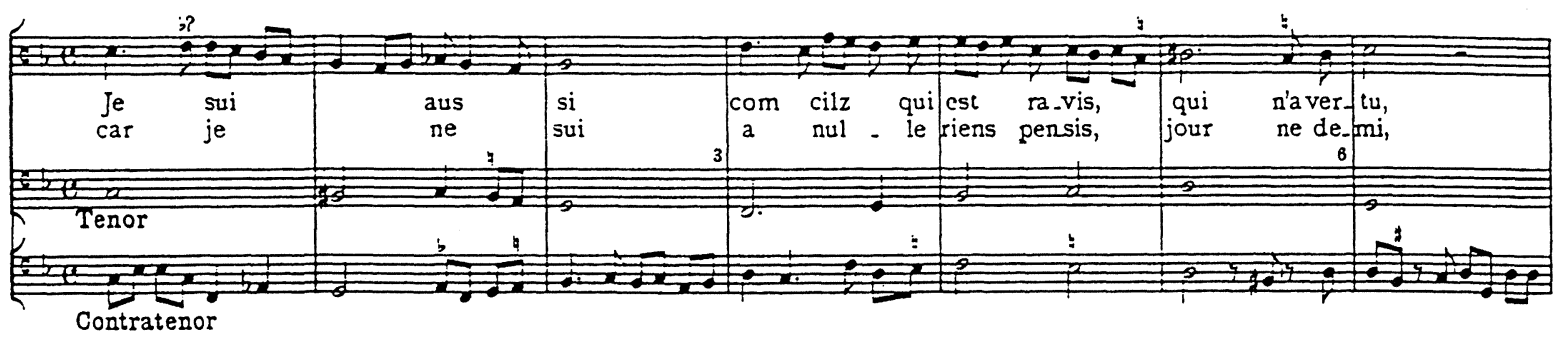

Ballade 20. Je suis aussi

Several of the later ballades, however, including some written in the years just before the Voir dit, (Nos. 25, 26, 28) are transmitted in the various manuscripts only as three-voice works. And, as several recent studies have noted, ${ }^{14}$ most of these seem to reflect a new and different approach to vertical sonorities. A significant number of them are based on $\mathrm{C}$ as the primary cadence, often alternating with $\mathrm{D}$ as the secondary close, and they tend to exploit the octave-fifth sonorities of the lower range. Perhaps the best example before the ballades of the late group is ballade 28 , Je puis trop bien: ${ }^{15}$

12. K. Moll, "Structural Determinants in Polyphony for the Mass Ordinary from French and Related Sources (ca. 1320-1410)," Ph.D. diss. Stanford Univ. 1994; see especially pp. 68-88.

13. For the views of Ernst Apfel regarding "expanded two-voice counterpoint" see K. Moll, Op. cit., pp.199f.

14. H. Kühn, Op. cit.; D. Leech-Wilkinson, Op. cit. 1993; Wulf Arlt, "Machauts Pygmalion Ballade," Musikalische Interpretation...Symposion zum 80. Geburtstag von Kurt von Fischerÿ, Zurich 1993, ed. J. Willimann and D. Baumann (Publ. der Schweiz. Musik-forsch. Gesellschaft, Ser. II, Vol. 38), Bern etc. 1999, pp.23-57.

15. For an in-depth analysis see M.L. Göllner, Op. cit. 1989 and, along similar lines, W. Arlt, Op. cit. 1999. 


\section{Example 4}
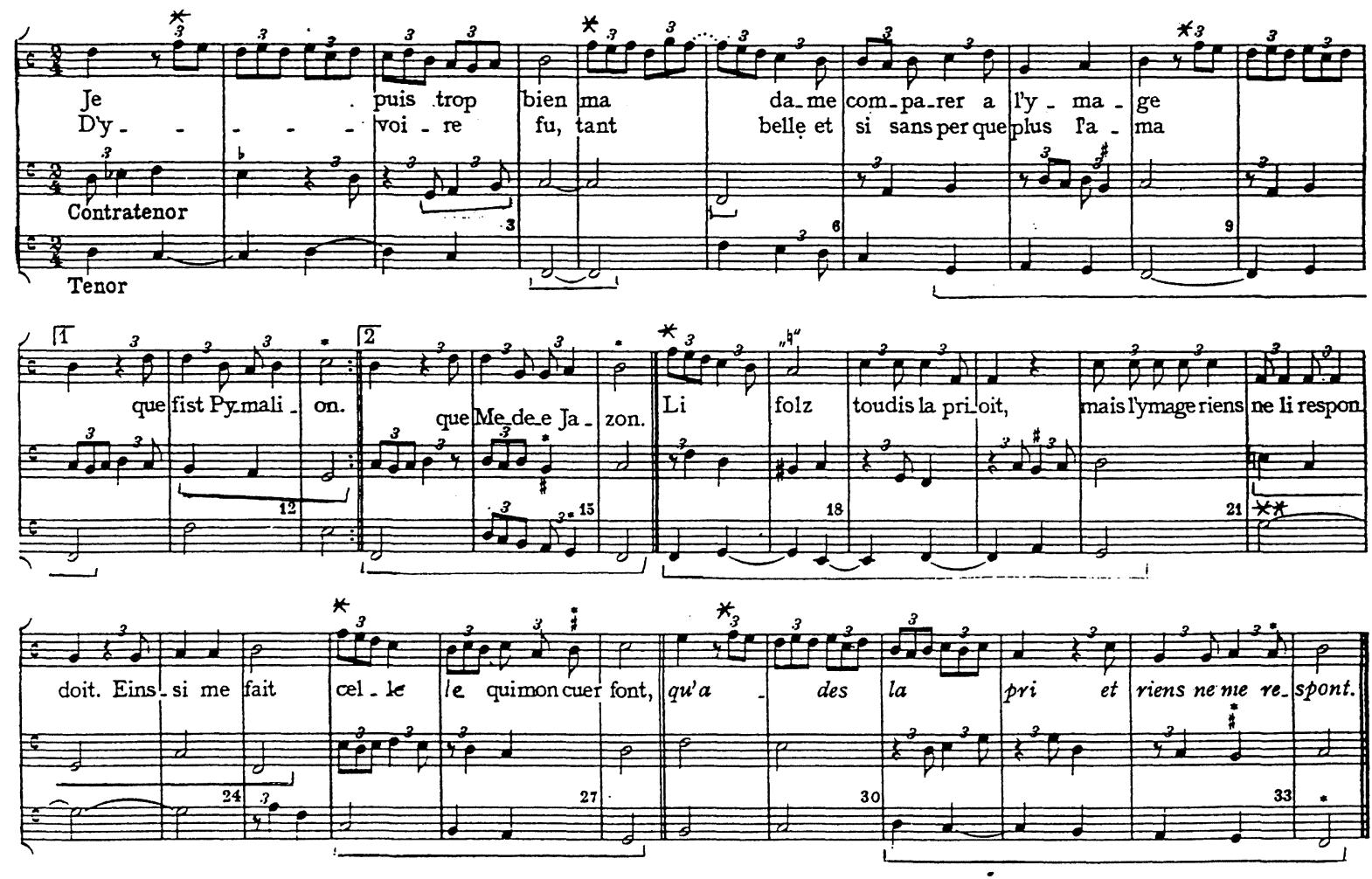

B28, Je puis trop bien

This piece alternates consistently between the two sonorities on $\mathrm{C}$ and $\mathrm{D}$, and in so doing tenor and contratenor trade off in sounding the lowest note. Since the interval relationship between Superius and Tenor remains technically correct as far as the rules of counterpoint are concerned, it can still be maintained that these two voices were composed first. Main cadences, in particular, still end with the octave between Superius and Tenor, while the Contratenor fills in the fifth above the Tenor to form a fourth with the Superius (see mm. 4,9 and the endings of the two main sections). The secondary ending, however, forms a third between Superius and Tenor with the Contratenor on the low D. And in the second part (mm. 22-24), where the upper voice lies below the long-held Tenor on high d, it is again the Contratenor which assumes responsibility for the basic tones of the sonorities on both low D and C (mm. 23-25). In listening to the piece, moreover, the primary importance of the low range cannot be ignored, and this in turn presupposes the contratenor as a necessary component. ${ }^{16}$ Although Superius and Tenor still cross

16. On the question of "dispensability" see K. Moll, Op. cit. 1994, pp.201f: ..."from the mere fact that two voices comprise a structural contrapuntal framework, it does not necessarily follow that those voices comprise a "complete composition."” 
in some cases (see above), there is thus a clear tendency to pair Tenor and Contratenor as far as range is concerned, and, more importantly, as the basis of the primary sonorities.

All of the settings of the late group of lyric poems which were included in the Voir dit reflect this new ideal, even though they are based on different pitches, namely low $\mathrm{C}$ (B 33,34 and R17), D (B 32) and even B-flat (B 36). Here, then, Machaut seems to have envisioned a new kind of vertical sound, based on the lower octave, and has realized it by inventing a new method for composing his three-part works. ${ }^{17}$ Several people, including myself as well as Wulf Arlt and Leech-Wilkinson, have noticed this change, ${ }^{18}$ but the old ideal of the two-voice basis is so firmly entrenched in the minds of scholars that it is very difficult to make a convincing case for the innovation. As a result, remarks on the subject have generally been confined to a single piece and have not formed the main focus of individual studies. In his recent work on the Machaut Mass, which he also dates in the 1360s, and in subsequent articles, Leech-Wilkinson has gone furthest in describing the new phenomenon, insisting that the whole must have been conceived before the individual voice parts, and that these can no longer be assigned separate functions. ${ }^{19}$

Since this view must have an important influence on performance, I would like to look at the ballades in question more closely. Rather than concentrating, as he does, on the vertical sonorities and dissonances themselves, I would like to link this new sound ideal to the phenomenon of the rhythmic motives. Although these two aspects, the vertical sonorities and the rhythmic motives, have generally been treated separately, I believe that the two go hand in hand. For important innovations in rhythm are likewise evident in the late ballades and they are in fact inseparably bound to the new sound ideal.

I would like, therefore, to focus for the remainder of the article on two specific rhythmic formulae, one of which is confined to a single mensuration. This one emerges only in the late works and can, I believe, be followed in its developmental phases as a kind of experiment in the new technique emvisioned by Machaut. This takes on various forms and appears to have been finally perfected, to judge from its composer's own comments, in ballade 33, Nes qu'on porroit. In sending it to his lady Machaut writes the recently oft-quoted advice: "And on my faith, it has been a long time since I have composed anything so satisfying... Please know it as it is written, without adding or subtracting anything." 20

The motif in question is actually not a single, fixed pattern but rather one which can be varied, a feature which is vital to its use. Since it respects the boundaries of the triple breve, it can occur only in perfect time and major prolation, or in modern editions $9 / 8$ time, and rests on the displacement by a minim of an imperfect breve within the unit of a perfect breve. Its various realizations include the following:

17. As Leech-Wilkinson notes (Op. cit. 1993, pp.56f), this can also be applied to the non-isorhythmic movements of the four-voice Mass.

18. See the articles quoted above in footnotes 5,9 and 14 .

19. D. Leech-Wilkinson, Op. cit. 1993, pp.56f.

20. Letter 10, quoted in the new edition (see fn. 9 above), p.125. The use of this letter by modern scholars can serve as an excellent example of the gulf which still separates experts in the literary and musical fields. Although both quote this letter frequently, they extract completely different parts of it to illustrate their points. Compare, for example, the parts familiar to us as quoted by Ludwig in his edition of the Werke, (Vol. II, Leipzig 1928, pp.54f), with those cited by Kevin Brownlee in his thorough analysis of the Voir dit, Op. cit., 1984, p.106. 


\section{Example 5}

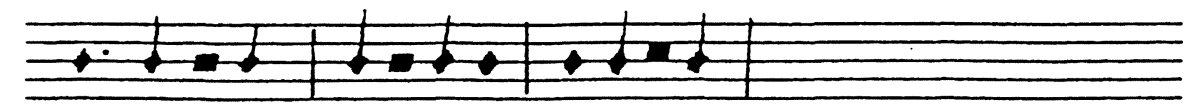

The other motive so commonly found within the same mensuration is not confined to this measure. It can and does occur just as frequently with major prolation in imperfect time:

\section{Example 6}

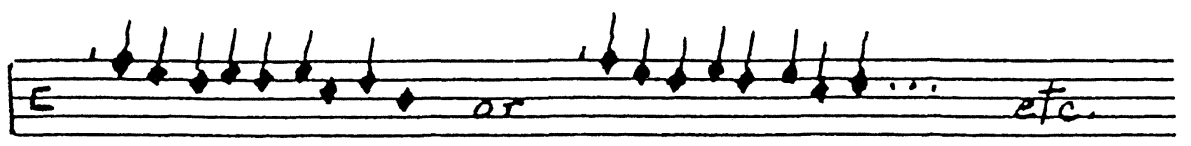

This second motive, as already noted by various scholars, is shared among a good number of the ballades, including several which can be dated shortly before the Voir dit (see above, Example 4). It is not, however, found in earlier ballades, such as No. 10 (Ne penses pas), which is also in triple mensuration. This motif occurs only in the Superius part and is generally independent of the text declamation, a fact which may have some influence on performance.

Of the five works contained in the group of the late chansons of the Voir dit (see above), three are notated in perfect time and major prolation, and all of these exhibit the two motives under discussion. These are, moreover, used in strictly separate ways. The second, more common motive appears here, as in the earlier works, exclusively in the texted superius, even though it functions consistently as a kind of ornamental figure, not involved in the declamation of the text. The rocking motive of the displaced breve, on the other hand, is confined with only a few exceptions to the lower two voices, and its use varies among the three ballades of the late group.

In Ballade 32 (Ploures dames), probably the earliest of the three, with the main cadence on $\mathrm{D}$, it is clearly an ornamental figure applied to the Contratenor to distinguish this part from the more regularly moving Tenor. The three parts are, in other words, still distinguished rhythmically from each other. The Superius employs the minims of motif number two, indicated here as B, while the Tenor moves for the most part in slower values: semibreves or even breves. The new motif, here A, enters the rhythmic mosaic as a kind of ornament found almost exclusively in the Contratenor, where it occurs frequently against the more basic movement of the Tenor. In this respect, that is, the Contratenor, still similar to earlier practice, is used as rhythmic enlivenment of the texture. (See, however, the final measure of the first ending, where the Tenor presents the motif all by itself as a kind of transition back to the beginning.) In noticeable contrast, however, to this separation of rhythmic function, the two lower voices alternate steadily in presenting the low note or basis of the sonority (see underlined passages). Although rhythmically distinct, the two lower voices are virtually equal partners when it comes to range: 


\section{Example 7}
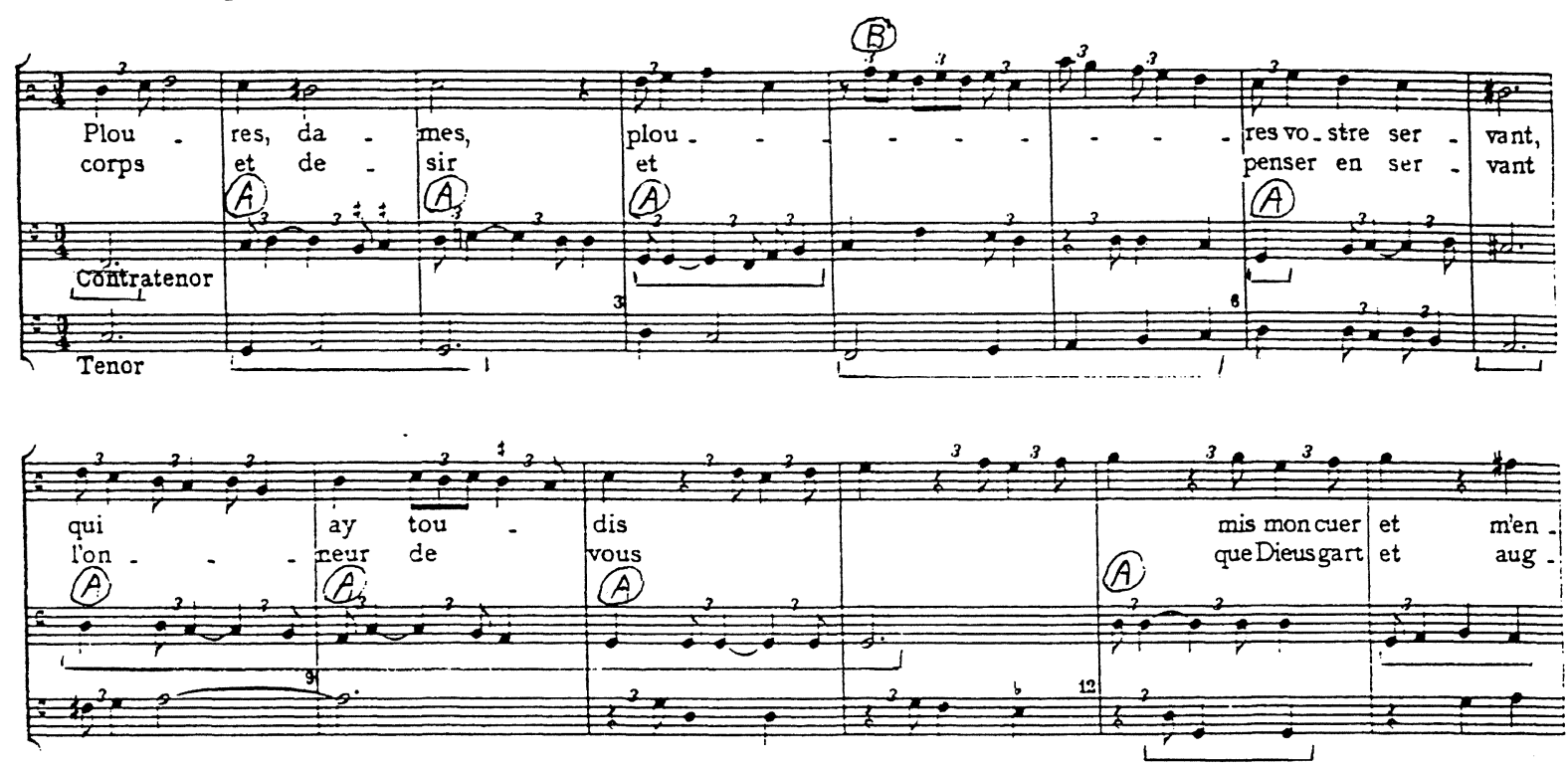

$\sqrt{1}(B)$

(B)

(B)

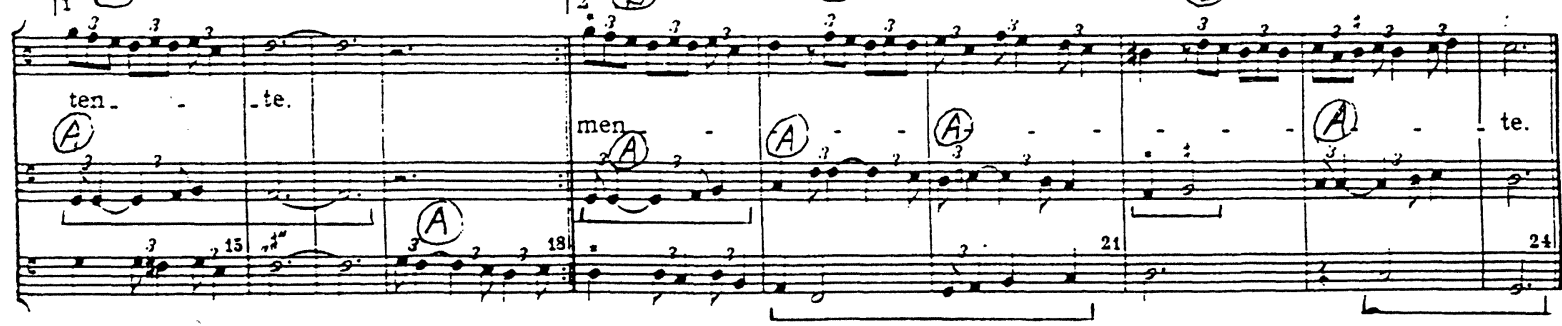

In Ballade 36 (Se pour ce muir), centered on B-flat, this relationship shifts somewhat. Both of the lower voices employ the new motif, at times even presenting different versions of it simultaneously, while the upper voice continues with its second motif. The rhythmic mosaic is, in other words, a good deal more complex in this ballade:

\section{Example 8}

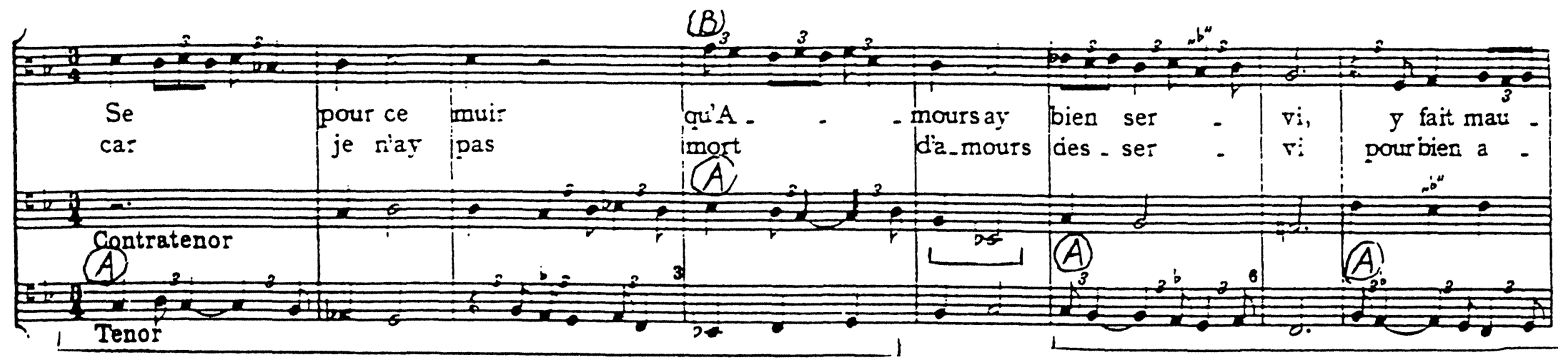




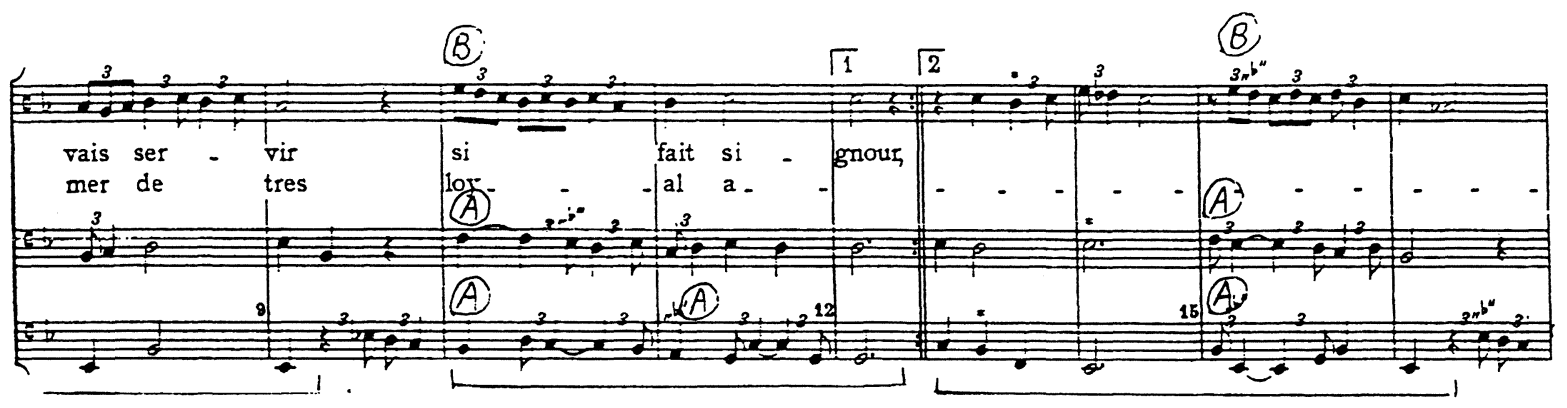

Interestingly, this cooperation is not, however, extended in the same manner to the vertical sonorities, whose lowest tone is, with only very few exceptions, provided by the Tenor.

In Ballade 33 (Nesqu'on porroit), centered like so many of the earlier 3-voice ballades on $\mathrm{C}$, Machaut appears to have realized his new ideal: both of the lower voices alternate not only in presenting the base of the sonority but also in their rhythmic function, i.e straightforward emphasis on the three semibreves of the perfect breve versus ornamental displacement using the new motif. This exchange occurs consistently throughout the piece, thus uniting the two lower voices as equal partners set against the Superius, which is differentiated both by virtue of its range and by its use of the second rhythmic motif. In his letter from the Voir dit (No. 10) Machaut actually refers to both lower voices as Tenors and praises their smooth flow. ${ }^{21}$

\section{Example 9}
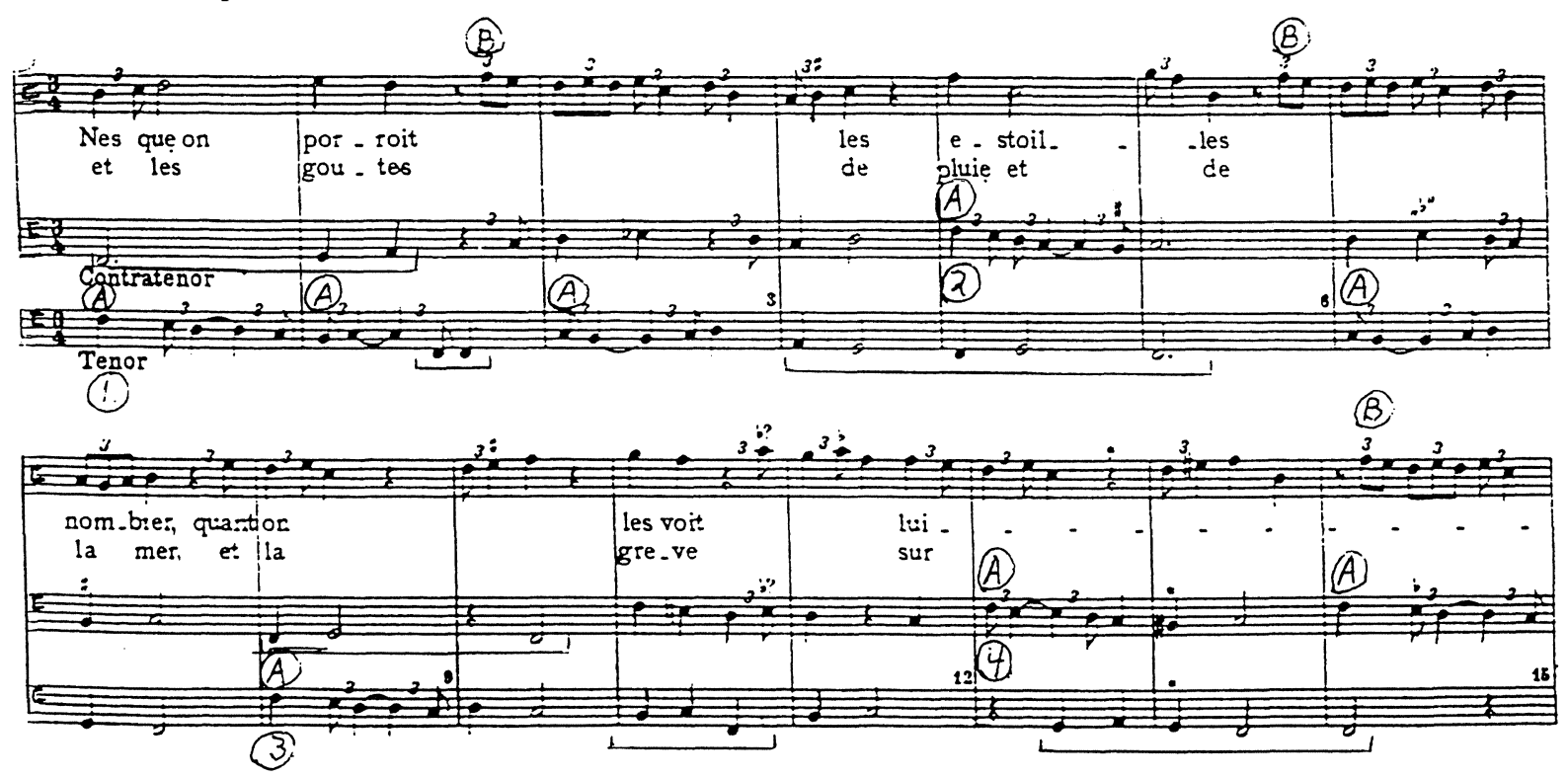

21. "et sont les tenures aussi doulces comme pappins dessalés" (see the new edition, p.125).

\section{0}

(c) Consejo Superior de Investigaciones Científicas Licencia Creative Commons 3.0 España (by-nc)
Anuario Musical, 56 (2001)

http://anuariomusical.revistas.csic.es 
Here, then, I would have to conclude that, perhaps in contrast to the long movements of the Mass, linear movement is still a main concern. Indeed Machaut has managed to enhance this aspect of the composition by his use of rhythm and rhythmic motives to characterize the parts, differentiating the Superius from the two, now equally important Tenors, while realizing a new ideal of vertical sonority. And this has, I believe, repercussions for both edition and performance. We do need a new edition, at least of the secular polyphonic works, one which would reflect more accurately the original mensuration and which would pay more attention to variations in the text underlay. And performance of these later ballades should, I feel, stress more clearly the rhythmic aspect to clarify the differences or similarities among the voices, i.e. precisely the linear movement of each individual voice. If this is made clear, the vertical sonorities will emerge by themselves, as it were, but in a way which reflects the constantly shifting mosaic of the rhythmic texture. $^{22}$

22. For further discussion and a different interpretation see D. Leech-Wilkinson, Op. cit. 1993, pp.51ff. 